\title{
REG3A wt Allele
}

National Cancer Institute

\section{Source}

National Cancer Institute. REG3A wt Allele. NCI Thesaurus. Code C105383.

Human REG3A wild-type allele is located in the vicinity of $2 \mathrm{p} 12$ and is approximately $3 \mathrm{~kb}$ in length. This allele, which encodes regenerating islet-derived protein 3-alpha, may play a role in both the proliferation and differentiation of islet cells. 